their nests with plant lice. ${ }^{1}$ Perhaps S. conestogorum also normally makes its nest in such twigs and only occasionally accepts galls. In any case, it is not a far cry from pithy twigs to pithy cynipid galls.

This species is, I believe, here recorded for the first time from New Jersey. It was described from specimens obtained in Pennsylvania. $^{2}$ I am indebted to Mr. Rohwer for the identification of the New Jersey specimen.

\title{
NOTES ON THE OCCURRENCE OF SOME ECONOMIC INSECTS NOT HERETOFORE RECORDED FROM NEW JERSEY.
}

\author{
By Harry B. Weiss, \\ New Brunswick, New Jersey. \\ Gracilaria azaleæ Busck.
}

This species has been noted in several greenhouses in northern New Jersey. The small larvæ turn over the tips and edges of azalea leaves and feed therein causing them to turn black and die. Pupation takes place in a silken, whitish cocoon usually attached to the leaf near where the larva has been feeding. This insect has also been taken in the larval and pupal stages on azaleas imported into New Jersey from Belgium. As yet, it has not become a serious greenhouse pest, probably because azaleas as a rule are not carried over until the next season or grown by most florists. After being forced, practically all are sold and fresh ones imported the next year.

Kaliosysphinga ulmi Lund.

This saw-fly leaf miner was noted at Westfield, N. J., during the summer of 1914, doing noticeable but not serious damage to the foliage of elm trees. The mines were irregular and blotch like in appearance. In Smith's 1909 list, it is mentioned only as being sure to occur in New Jersey.

1 Comstock. Manual for the study of insects, ed. 1913, pp. 655-656.

2 Rohwer, Proc. U. S. Nat. Mus., Vol. 40, 1911, pp. 557-558. 
Coleophora limosipennella Dup.

This elm pest which is also recorded in Smith's 1909 list as being sure to occur in New Jersey was found definitely at Hackensack during the summer of 1914 feeding on elms. It is also known as the European elm case bearer, the larva-living in a flattened case with serrated upper edge. The damage deing done, however, was not serious.

\section{Monarthropalpus buxi Lab.}

This leaf miner was reported during the summer of 1914 from a private estate in Peapack, N. J., where it was injuring a box hedge. The maggots mine the leaves and in bad infestations much of the foliage is lost. This pest is known to occur in Maryland and New York but has not heretofore been recorded from New Jersey.

\section{Leucaspis bambusæ Kuwana.}

During the summer of 1911, bamboo growing around the edges of a pond in a nursery at Riverton, N. J., was found to be badly infested by what was undoubtedly the above scale insect. The insects were so thick around the joints of the plants that they resembled patches of snow. In spite of their numbers, however, they did no appreciable damage. Mrs. Fernald, in her catalog of the Coccidæ of the World, gives the habitat of this scale as Japan and the infested plants in this case were originally imported from that country. Mr. E. R. Sasscer, to whom some of the insects were only recently sent, replied that while the lobes were somewhat worn he was of the opinion that it was L. bambusoe. Unfortunately this splendid infestation was practically wiped out by the bamboo being cut back on account of its ungainly size.

\section{Merodon equestris $\mathrm{L}$.}

This species known as the Narcissus fly was found in the larval stage only, at Orange, N. J., during October, 1913. The party on whose place it was found destroyed all suspicious bulbs and the following spring, nothing could be found, Since that time, however, reports have been made from that vicinity mentioning a maggot found in iris roots which had been injured by Macronoctua onusta Grote and I am of the opinion that these may be larvæ of the Lunate onion fly, Eumerus strigatus Fallen, inasmuch as Dr. E. P. Felt has recorded this species as occurring under such conditions. 

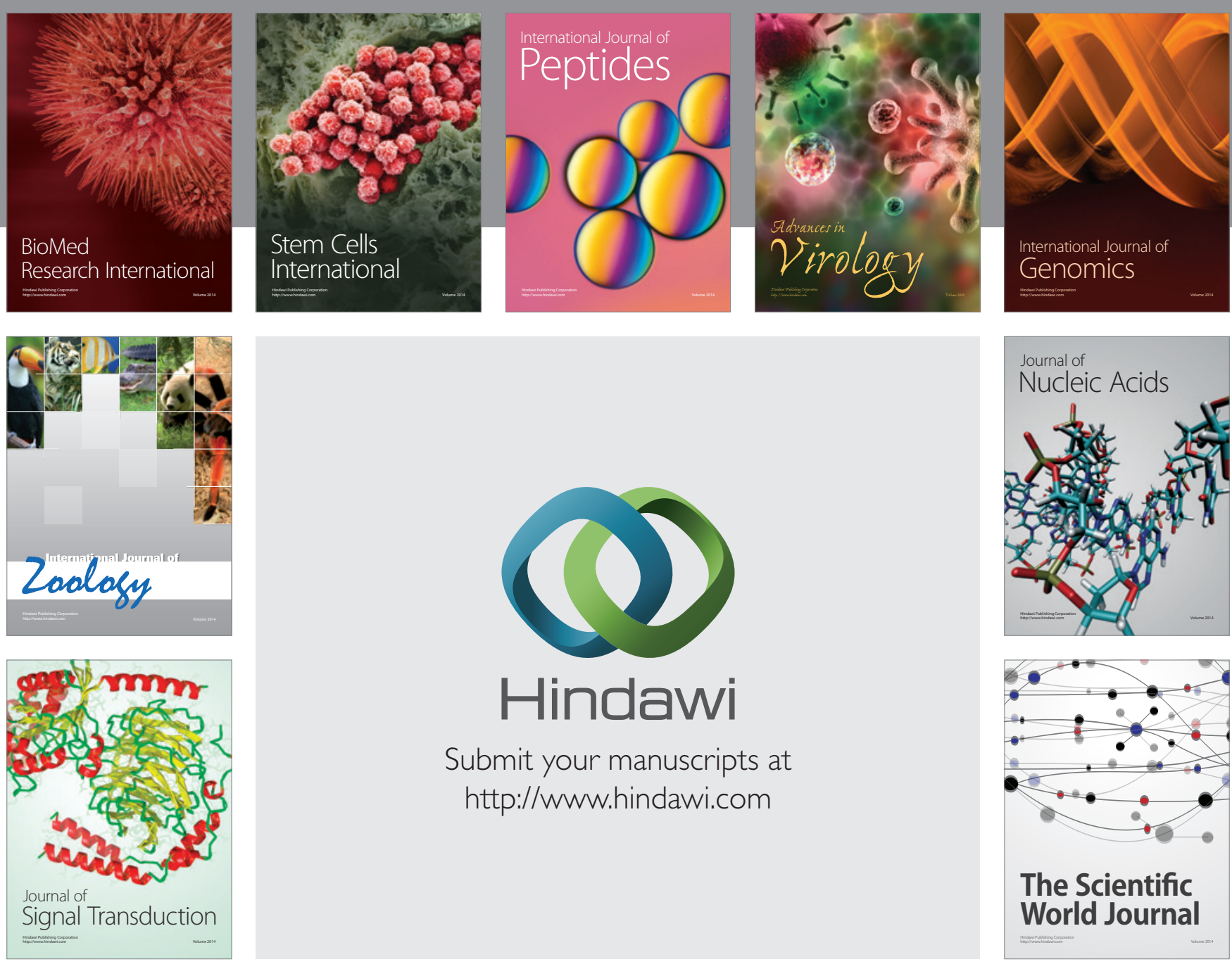

Submit your manuscripts at

http://www.hindawi.com
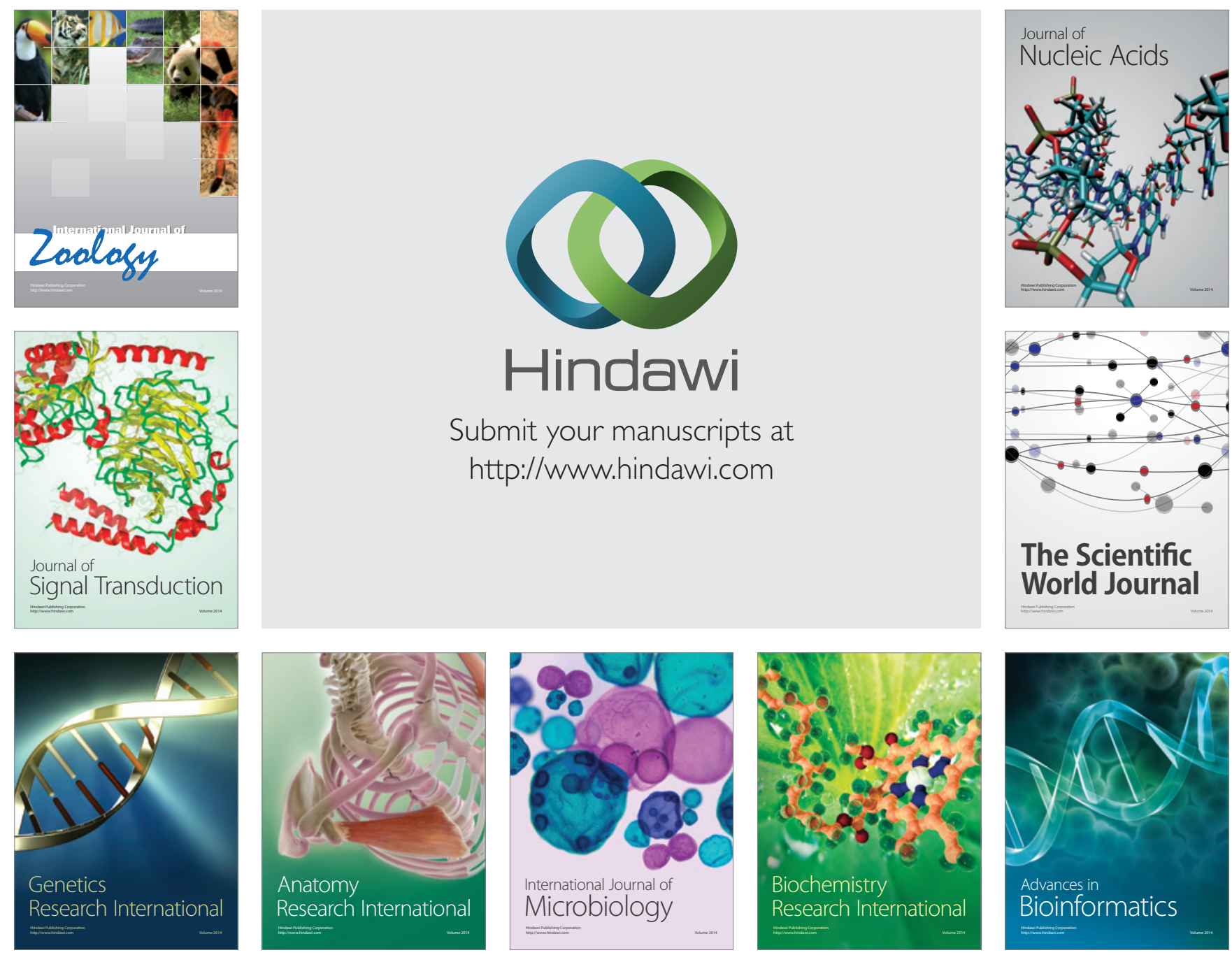

The Scientific World Journal
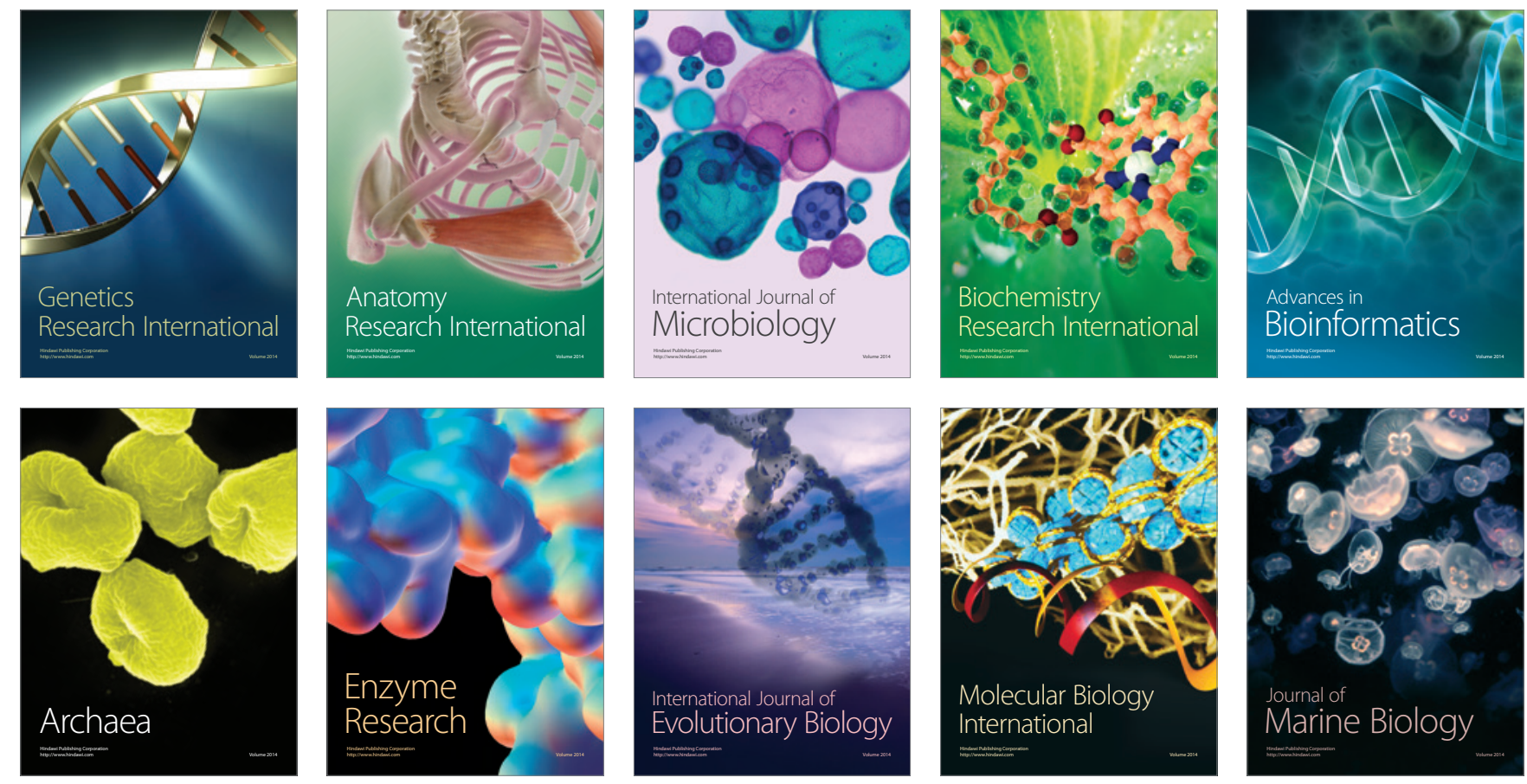